„Gdzie się dwóch światów stykają drogi ..." Problem wojny i postępu dziejowego w poglądach Cypriana Godebskiego

Artur Timofiejew 


\section{Artur Timofiejew}

\section{„Gdzie się dwóch światów stykają drogi...”. Problem wojny i postępu dziejowego w poglądach Cypriana Godebskiego}

$\mathrm{M}$ etafora „dwóch światów” użyta w tytule wywodu pochodzi z wiersza Cypriana Godebskiego Do Jedrzeja Horodyskiego i bezpośrednio odsyła — co poeta sygnalizuje w przypisie do historiozofii Herdera, pośrednio zaś, poprzez tezy niemieckiego filozofa, do bogatej sfery znaczeń symbolicznych, związanych z faktem przełomu XVIII i XIX stulecia ${ }^{1}$. Styk „dwóch światów” byłby zatem semantycznie tożsamy z końcem „starego” i rozpoczęciem „nowego” wieku, z zamknięciem pewnej fazy rozwoju historycznego i przejściem do następnej. I w myśli Herdera, i w przypadku symboliki przesilenia epok funkcjonującej w obrębie świadomości zbiorowej zetknięcie się „dwóch światów” konotuje zmianę historyczną, finał „starego” i początki „nowego” - a tym samym wskazuje na czas jako wymiar, w którym realizują się określone wartości.

Wiek „wychodzenia człowieka z niepełnoletności” zamknął się zarówno w skali europejskiej, jak i polskiej serią wstrząsów; Wielka Rewolucja Francuska i polityczna likwidacja Rzeczypospolitej mogły uchodzić za swoiste alegorie unicestwienia „starego” świata. Narodzinom „nowego”, u progu kolejnego wieku również towarzyszyły gwałtowne perturbacje, wywołane, jak powszechnie sądzono, aktywnością wzeszłej już gwiazdy „geniusza wojny” — Napoleona. W tym kontekście zmiana historyczna nosi wszelkie znamiona procesu przebiegającego z niebywałą dynamiką, rewolucyjnego w swojej istocie, przeobrażającego szybko i gruntownie rzeczywistość społeczną i — nade wszystko - polityczną. W odczuciu współczesnych proces ów utożsamiał się z ogarniającą Europę wojną, z którą łączą się nierozdzielnie kataklizmy w przyrodzie: erupcje wulkanów, trzęsienia ziemi, powodzie. O współistnieniu wojny-zaburzenia w historii z groźny-

\footnotetext{
1 Zob. A. Alcksandrowicz, Z problematyki nou'ego wieku. Wokót Świq̨tyi Sybilli, „Wiek Oświccenia”, t. 16, Przełom wieków, Warszawa 2000, s. 9-32.
} 
mi anomaliami natury (charakterystycznym także dla późniejszego, romantycznego stylu myślenia) mówi wprost podmiot w wierszu Do Jędrzeja Horodyskiego:

Czy się raz jeszcze niebo uwzięło

Zniszczyć w zapale rąk własnych dzieło? (...)

Tam z ognistego Wulkan warsztatu

Okropne ciosy zadaje światu,

Tu Gradyw srogi, ulew i burze

Grożą naturze.

Kiedyż tych koniec klęsk dla Europy?

Tam łzę wyciska los Partenopy,

$\mathrm{Tu}$ jeszcze ciosy przeszłego wieku

Pamiętne człeku...

Przebacz, Jędrzeju, że zapęd muzy

Kryśli ci lawy, potopy, gruzy

I że się smutnym rozwodzi głosem

Nad świata losem ${ }^{2}$.

Dwa stykające się ze sobą „światy” można przeto zinterpretować jako ścisły związek natury i historii, gdyż - jak zauważa badacz problemu:

...myśl oświeceniowa uznała historię za jeden z najważniejszych czynników determinujących istnienie i rozwój człowieka jako podmiotu życia zbiorowego określonego przez dostępne w nim wartości. Drugim pozostawała jednak nadal przyroda ${ }^{3}$.

Ale w tymże samym wierszu ukazane jest jeszcze inne znaczenie „dwóch światów”: oto, by odczytać sens wojny i współgrających z nią zaburzeń w przyrodzie, a mówiąc inaczej — by należycie ocenić zmianę historyczną, należy spojrzeć na nią z innej niż historyczna perspektywy:

Ty ze wzniesionej nauki wzgorza

Patrzysz spokojnie na szturmy morza,

Gdzie okręt życia pędzą na skały

Wichrów nawały.

Ty na tej mecie stoisz bez trwogi,

Gdzie się dwóch światów stykają drogi $(\ldots)^{4}$.

2 C. Godcbski, Do Jędrzeja Horodyskiego, w: idem, Wybór wierszy, opr. Z. Kubikowski, Wrocław 1956, s. 71, 72.

${ }^{3}$ Z. J. Czarnecki, Wartości i historia. Studia nad refleksja filozoficznq o ludzkim świecie, Lublin 1992, s. 94.

${ }^{4}$ C. Godebski, op. cit., s. 72. 
Wzgórze „Wzniesionej nauki” zapewnia, nie tylko zresztą adresatowi tego wiersza, widzenie historii z perspektywy mędrca-stoika.

Przyjaciel Godebskiego od czasu konspiracji lwowskiej i warszawskiej, a później współtowarzysz emigracyjnej tułaczki, aktywny przedstawiciel Deputacji Polskiej i zwolennik radykalnego republikanizmu, filozof Józef Kalasanty Szaniawski tak charakteryzował zalety stoików starożytnych:

...każą Stoicy wznosić się człowiekowi do uwagi nad położeniem swoim w ogromie tworów natury i nad cząstka, jaką on tam zajmuje: tym sposobem wyrywają go z tego nikczemnego punktu, w którym go krótkooki zamyka egoizm, rozprzestrzeniają przed nim sferę obowiązków względem siebie samego, względem familii i przyjaciól, względem ojczyzny i względem rodu ludzkiego 5 .

Wzniesienie się człowieka „do uwagi nad położeniem swoim” i rozprzestrzenienie przed nim sfery „obowiązków (...) względem ojczyzny i względem rodu ludzkiego” jako element zdefiniowanej przez Szaniawskiego postawy stoickiej może być potraktowane również jako wyznacznik pewnej postawy historycznej wobec konkretnej rzeczywistości, a mianowicie takiej postawy, która wynika z uświadomienia przez podmiot konieczności refleksji nad własnym miejscem w „przestrzeni” już nie „tworów natury”, lecz historii, a nadto z uświadomienia własnego, aktywnego uczestnictwa (poprzez wypełnianie obowiązków względem ojczyzny i ludzkości) w jej kształtowaniu. Uwaga Szaniawskiego o powinnościach człowieka względem zbiorowości, poparta autorytetem Lukianowej sentencji „Nie dla siebie samych, ale dla świata całego rodzimy się!”, jest w swojej istocie wyrazem oświeceniowej definicji obowiązku pojętego jako sposób kształtowania świata, także świata historycznego. Jeśli zaś obowiązkowi, będącemu moralną regulacją czynu, przyznaje się funkcję historiotwórczą, to rozwój dziejów musi utożsamiać się z rozwojem moralności. Tożsamość tę przedstawia Godebski następująco:

Po nauce obyczajów ma pierwszeństwo wiadomość dziejów. Pierwsza jest świetnym znamieniem usiłowań człowieka; druga ukazuje jego postęp na drodze udoskonaleń moralnych ${ }^{7}$.

Historia jest zatem uzewnętrznieniem postępu moralnego człowieka, jest — jak określiłby ją Condorcet - obrazem "postępu ducha ludzkiego" i jako taka nie może zawierać w sobie nic przypadkowego, zbędnego czy bezsensownego ${ }^{8}$.

Dwa „światy”, na których styku znajduje się człowiek, to wedle byłego legionisty także „świat” niewzruszonej moralności (respective stoickiej mądrości) i „świat” zmiennej historii. Skoro jednak zwornikiem tych „światów” jest człowiek, to historia musi być pojęta, najogólniej rzecz biorąc,

${ }^{5} \mathrm{~J}$. K. Szaniawski, O znamienitych systemach moralnych starożytności rzecz krótka, ,, Roczniki Towarzystwa Warszawskiego Przyjaciół Nauk", t. 2, 1803, s. 239-240.

${ }^{6} \mathrm{Ibidem}, \mathrm{s} .240$.

7 C. Godebski, Historia, „Zabawy Przyjemne i Pożyteczne”, t. 3, 1804, s. 23.

${ }^{8}$ Zob. Z. J. Czarnccki, op. cit., s. 89-90. 
jako droga realizacji, samospełniania się człowieczeństwa. Rolę wyznacznika i zarazem miernika postępu dziejowego powierza Godebski russoistycznie potraktowanej idei „wieku złotego”.

Poglądy te znalazły swój najpełniejszy wyraz w warstwie ideowej Grenadiera-filozofa..., powieści osnutej na materiale autobiograficznym, przede wszystkim w rozdziałach IV i V, opowiadających o spotkaniu dwóch polskich legionistów z alpejskim pasterzem.

Pasterz ów jest literackim przetworzeniem pierwowzoru nakreślonego piórem przyjaciela Godebskiego, generała Amilkara Kosińskiego, w liście z początku roku 1803. Rozgoryczony przeobrażeniami w świecie polityki eks-generał I Legii polskiej pisał:

Ja jestem przekonany, iż kiedy sztuka rządzenia, która tak śpiesznym krokiem dąży na początku dziewiętnastego wieku do doskonałości, przyjdzie do zamierzonego celu wytrzeć z wyobrażenia nawet ludzkiego znajomość praw człowieka, kiedy już ludzi nie będzie na caléj przestrzeni ziemi, lecz tylko tyrany i niewolnicy, góral wtenczas nawet nie przestanie być człowiekiem. - O, gdybym Ci mógł oddać te uczucia, to wyniesienie duszy, których ja doświadczyłem, odwiedzając wyniosłe Alp szczyty, zgodziłbyś się ze mną, iż mało jest być urodzonym na téj ziemi, gdzie majestat monarchy pierwszym był tylko sługą narodu, lecz trzeba być mięszkańcem gór, ażeby czuć tę całą godność człowieka'.

Narrator powieści i jego przyjaciel, szukając schronienia przed burzą, napotykają gospodarza alpejskiej ustroni i już od pierwszych chwil postrzegają w nim człowieka szczęśliwego — żyjącego W zgodzie z samym sobą, czyli praktykującego cnotę (o jego wiedzy moralnej świadczą formułowane przezeń zasady postępowania), a więc wewnętrznie wolnego i rozumiejącego, czym jest wolność. Gościnny pasterz wyznaje russowską religię naturalną, za której podstawy uważa ideę Boga wywiedzioną z porządku natury i z moralnej waloryzacji tego porządku, łączność z Bogiem poprzez uczucia i czynienie dobra (russowskie kategorie serca i szczerości), nie zaś poprzez jakąkolwiek — tradycyjną czy rewolucyjną — formę kultu, wreszcie ideę nieśmiertelnej duszy jako swoistą konsekwencję ladu moralnego.

Tak pojętemu stanowi szczęścia wewnętrznego towarzyszy szczęśliwość bytowania zewnętrznego: zdrowie, umiarkowany dostatek, harmonia małżeńskiego pożycia.

Postrzegany i całkowicie akceptowany (to znaczy nie budzący jakichkolwiek wątpliwości ani wewnętrznego sprzeciwu) przez legionistów stan szczęśliwości owego Sabaudczyka skłania jednego z nich, narratora, do sformułowania ciągu filozoficznych uwag. Pierwsza przybiera postać sentencji „Nieszczęście (...) od nas pochodzi, bo szczęście naszym jest dziełem” "10 i odnosi się do człowieka w ogóle jako głównego sprawcy dwóch możliwych, wzajemnie przeciwstawnych stanów, a ściślej rzecz ujmując — do człowieka będącego podmiotem wolności, ponieważ wolność wyboru, czyli określone użycie wolnej woli, stoi u podstaw szczęścia lub nieszczęścia. Pozostałe

\footnotetext{
${ }^{9}$ Generat Amilkar Kosinski we Wloszech 1795-1803, opr. W. Kosiński, Poznań 1877, s. 350-353.

${ }^{10}$ C. Godebski, Grenadier-filozof. Pouvicśc praudziwa ưjęta z dziennika podróży roku 1799, opr. Z. Kubikowski, Wrocław 1952 , s. 25
} 
uwagi, układające się w czerdziestoośmiowersową elegię na temat „wieku złotego”, dotyczą człowieka-obywatela jako autora swojego konkretnego, realizującego się tylko i wyłącznie na płaszczyźnie społecznej, szczęścia (czy, odpowiednio, nieszczęścia), które, analogicznie, wynika z właściwego wykorzystania wolności obywatelskiej, wyboru — jako normy własnego postępowania — dobra ogółu i odrzucenia - jako takiej normy — egoistycznie pojętego dobra własnego:

Człek swe szczęście zakładał na szczęściu współbraci ${ }^{11}$.

Zasadniczym warunkiem dokonania takiego wyboru jest wsłuchanie się w głos serca rozumiany russoistycznie jako sumienie, uczucie moralne ${ }^{12}$; niezafałszowany głos serca wyznacza „prawa” - w znaczeniu: prawidła — postępowania i zachęca do wkroczenia na drogę „cnoty”:

Wlasne uczucie prawem, a cnota zwyczajem $^{13}$.

Innymi słowy, uznanie „szczęścia współbraci” za normę własnego postępowania (dzięki czemu osiaggalne staje się także, jakby przy okazji, subiektywnie pojęte szczęście) możliwe jest tylko wówczas, gdy wolą podmiotu kieruje bezpośrednio „uczucie” — sumienie. Na ową bezpośrednią zależność aktów woli od głosu serca wskazuje narrator, stwierdzając, iż w „złotym wieku” ludzkości:

Zdań równość nienawiści nie była pochodnią,

Błąd umysłu był błędem, wady serca zbrodnią ${ }^{14}$.

Zło, „zbrodnia” utożsamia się z zafałszowanym głosem serca motywującym wolę, przy czym istota deprawacji sumienia-głosu serca polegać może albo na uleganiu własnym, uwolnionym spod kontroli rozumu namiętnościom, a tym samym na próbie połączenia i pogodzenia zarazem uczucia moralnego z pobudkami niższego rzędu, wypływającymi z czysto cielesnej strony ludzkiej natury (w „wieku złotym” „Żądze [były] niewolnikami, a rozum ich panem”), albo na przepuszczeniu głosu serca przez warstwę wywiedzionych z intelektu przekonań, „zdań” - co, rzecz jasna, natychmiast zapala "nienawiści pochodnię" 15 . W jednym i w drugim przypadku „wadę”

"Ibidem, s. 26.

${ }_{12}$ Zob. J. J. Rousseau, Emil, czyli o wychowaniu, tł. E. Zicliński, opr. J. Legowicz, F. Wnorowski, t. 2, Wrocław 1955, s. 122-123: „Działalność sumicnia przcjawia siç nic w sądach, lecz w uczuciach. Aczkolwick wszystkic pojęcia nasze pochodzą z zcwnątrz, ich occna uczuciowa tkwi w nas samych. I dziçki nicj wicmy, co jest dobre, a co złe w nas samych i przedmiotach (...). Znać dobro nie znaczy jeszczc kochać jc. Człowick nic ma wicdzy tcj wrodzoncj. Skoro jednak rozum nauczy go poznawać dobro, sumienic każe mu je kochać, i to uczucie jest wrodzone"; idem, Listy moralne, th. M. Pawłowska, w: idem, Umowa spoteczna..., opr. B. Baczko, Warszawa 1966, s. 578, 581-582: „Zcby dobro było dobrcm, musi ono nim być w glębi naszych serc (...). miłość dobra i nienawiść zła są nam dane z natury jak nasze własne istnicnic; tak więc, chociaż nasze idee przychodzą do nas z zewnątrz, uczucia, które je oceniają, są wewnątrz nas (...)".

${ }^{13}$ C. Godebski, op. cit., s. 25.

${ }^{14}$ Ibidem, s. 26.

${ }^{15}$ Zob. J.J. Rousscau, Emil..., op. cit., s. 117, 125: „Zbyt często rozum myli nas, mamy aż nazbyt wicle danych jemu się sprzeciwiać. Natomiast sumienic nigdy nic zawodzi. (...) Walcząc nicustannic z uczuciem naturalnym broniącym dobra powszechnego i $z$ rozsądkiem przemawiającym $w$ imieniu moich własnych interesów, do końca życia nic wyszedłbym z blędnego koła: miłując dobro czyniłbym zło. (...) Próżne są wysiłki oparcia cnoty na samym rozumic! Jaką bowiem trwałą podstawę możc dać rozum?”. 
serca jako organu sprawczego woli należałoby synonimiczne określić mianem heteronomii sumienia; sumienie jako czynnik pobudzający wolę ma być tylko głosem serca, tylko uczuciem moralnym (,własne uczucie prawem”); jeśli natomiast zmieni się w konglomerat głosu serca i czegoś dodatkowego, na przykład namiętności czy skonstruowanego przez umysł poglądu, czyli jeśli utraci swoją autonomię, wówczas zacznie wadliwie determinować wolę, co jest równoznaczne z niemożliwością osiągnięcia pełnego szczęścia, tak w wymiarze subiektywnym, jak i społecznym.

Życie „na łonie niewinnej prostoty”, jakie było udziałem człowieka w „złotym wieku” i jakie toczy współcześnie sabaudzki pasterz, oznacza zatem przede wszystkim russowską ars vivendi, postulującą prostotę moralną, czyli motywowanie woli czystym głosem serca, jako zasadniczy warunek osiągnięcia szczęścia; nie oznacza zaś egzystencji w pierwotnym, znajdującym się u początków historii ludzkości stadium rozwoju społecznego, w którym prostota zachowań utożsamiałaby się tylko $z$ ich prymitywizmem, a więc wskazywałaby pośrednio na ich przejściowość, na nieuchronność ich zmiany, czyli definitywnie odbierałaby pojęciu „wieku złotego” charakter postulatywny (jako ideałowi, do którego realizacji powinna zbliżyć się ludzkość), co jawnie przeczyłoby opcji narratora powieści.

Pasterz sabaudzki, chociaż „podobny swym ubiorem do mieszkańca Kanady” (czyli Indianina) i którego siedziba „to raczej buda niżeli chatka”, nie jest potomkiem Nipuanów ani przedstawicielem jakiejś alpejskiej Utopii; żyje w rzeczywistości historycznej, a jego górska ustroń stanowi jej organiczny fragment. Wtopienie owej enklawy szczęśliwości w bieg dziejów, czy — patrząc z punktu widzenia bohatera-narratora powieści - jej wyodrębnienie na zasadzie wycinka z szeroko rozumianej historii dokonuje się na dwa sposoby, a mianowicie poprzez informacje o relacjach łączących siedzibę pasterza z resztą świata i podkreślenie nieuchronności tych relacji oraz poprzez próbę ujęcia historii jako jedynej możliwej sfery realizacji wartości, czyli wskazanie na historię jako wspólną dla bohatera „w pasterskiej odzieży” i reszty ludzkości możliwość spełniania się człowieczeństwa.

Gościnny góral zna doskonale drogi wiążące jego siedzibę z Sabaudią, co w sposób symboliczny wyraża złączenie się górskich „prostych ścieżek” z „wielkim gościńcem”; sam nie odbywa wprawdzie dalekich podróży, ale „oddawać posługę podróżnym”, pełnić funkcję przewodnika doprowadzającego podróżnych do głównej drogi uznaje za swoją powinność, w związku z czym sporadycznie, w zależności od przypadku, odwiedza pobliską wieś. Musi jednakże regularnie opuszczać swoją ustroń i udawać się do miasta po to, by nabyć tam sól — właśnie sól, nie zaś narzędzia, odzież czy inne przedmioty codziennego użytku. Symbolika soli — substancji niezbędnej do życia - służy tu szczególnemu uwypukleniu koniecznej więzi między szczęśliwą, funkcjonującą na zasadzie mini-autarkii pasterską ustronią a rzeczywistością historyczną - i tym samym społeczną, więzi, która z pozoru tylko wydaje się zależnością jednostronną.

Historia bowiem uobecnia się także w życiu szczęśliwego Sabaudczyka w sposób bardziej dramatyczny, rzec by można, bardziej bezpośredni: oto jego siedziba jest wszakże w sensie geograficznym cząstką Sabaudii (pasterz znakomicie orientuje się w geograficznym położeniu swojej ustroni: zna sieć oplatających ją dróg, wie, gdzie leży Chambéry, umie nawet ocenić 
w przybliżeniu odległość dzielącą ,jego” górę od Rzymu), a zatem doświadczać musi tego samego, co reszta owej krainy - wejścia wojsk francuskich i przyłączenia do młodej Republiki. Rzecz jasna, wydarzenia te nie rozgrywają się na stokach góry zamieszkałej przez pasterza, ale obok niej; pasterz jednakże, jak sam zaświadcza, ma z nimi - w momencie, gdy opuszcza swoją siedzibę - naoczny kontakt, przeżywa je i komentuje. Wreszcie za symboliczne podkreślenie bezpośredniości związku pasterskiego życia z historią uznać wypada przejście pierwszego, anonimowego legionisty przez tę alpejską ustroń i pozostawienie przezeń tamże „skropionego łzami” napisu na kamieniu oraz przejście dwóch następnych żołnierzy, narratora i jego towarzysza, kierujących się, podobnie jak pierwszy, do Chambéry.

I chociaż szczęśliwy mieszkaniec alpejskiego zakątka wyznaje: „Ja ledwo wiem, że w Sabaudii są Francuzi" ${ }^{16}$, jednak postrzega szereg zmian o charakterze politycznym (przyłączenie Sabaudii do Francji), społeczno-prawnym (organizacja porządku społecznego wedle zasad wolności i równości), obyczajowym (utrata dominującej pozycji w sferze duchowego oddziaływania przez katolicyzm, próby upowszechniania rewolucyjnego kultu Rozumu), czyli, mówiąc ogólniej, postrzega zmianę historyczną i poszukuje jej sensu w perspektywie wartości moralnych. Historia jawi się sabaudzkiemu pasterzowi jako ciąg prób realizowania przez człowieka tych wartości, które konstytuuja jego człowieczeństwo, przy czym krytyczne nastawienie do owych prób (stwierdzenie, iż nie są one udane), podzielane zresztą przez narratora powieści, wyraźnie wskazuje z jednej strony na zbiorowość, na człowieka w sensie społeczności jako jej podmiot (rewolucyjna Francja „szczepi na rynkach miast drzewa wolności”, wysyła „posłańców rozumu”), z drugiej natomiast - na kierunek rozwoju dziejów (historia jakby chce zrealizować wartości, stąd nieustannie dąży do powszechnej wolności i pokoju). To, że owe próby są chybione, wcale nie przesądza o tym, by uznać je za bezsensowne i powstrzymać się od ich podejmowania; wręcz przeciwnie, wysiłek osiągania wartości jest wysiłkiem zdobywania pełni człowieczeństwa, chodzi tylko o to, by odbywał się wedle właściwej metody.

Tę metodę, którą zgodnie $\mathrm{z}$ duchem epoki nazwać by można sokratesowską ${ }^{17}$, ukazuje Godebski na przykładzie funkcjonowania alpejskiej autarkii, gdzie wartości składające się na pojęcie człowieczeństwa są praktycznie wciąż, dzień po dniu, osiągane. Nie odgórnie narzucone prawo, choćby najskuteczniej promujące owe wartości, i nie zbiorowość jako przedmiot tego prawa (a więc ktoś zewnętrznie przynaglony do realizowania wartości) zapewniają faktyczne spełnianie się człowieczeństwa, ale prawo wyprowadzone z siebie samego jako czlowieka, wewnętrznie zaakceptowane (jest to subiektywna podległość przekonaniu wewnętrznemu) i praktykowane indywidualnie, stwarza podstawę ukonstytuowania się jednostek w zbiorowość (prawo to jest wszakże identyczne w przypadku każdej indywidualnie pojętej jednostki) — właściwy podmiot realizujących się wartości ${ }^{18}$. Innymi słowy, jednostka w pełni moralna, to znaczy

\footnotetext{
16 C. Godebski, op. cit., s. 26.

17 Zob. B. Böhm, Sokrates im achtzehnten Jahrhundert. Studien zum Werdegange des modernen Persönlichkeitsbeu'ußtseins, Lcipzig 1929, s. 119.

18 Zob. B. Baczko, Demokracja ikonsenwatyzm w utopii J.J. Rousseau, „Archiwum Historii Filozofii i Myśli Spolecznej”,
} 
rozpoznająca dzięki głosowi wewnętrznemu swoje powołanie do czynienia dobra i żyjąca według tego powołania, stanowi podstawowy, nieredukowalny $\mathrm{i}$ konieczny element w strukturze procesu przyswajania wartości przez historycznie istniejącą zbiorowość. Takimi jednostkami moralnymi są w powieści Godebskiego — oprócz gościnnego pasterza i jego małżonki — tytułowy grenadier Jan Henry, sterany wiekiem i „usługami dla ojczyzny” gospodarz zajazdu w Pont-de-Beauvoisin, porucznik Martini, kapitan Michalewski i sam narrator. Tworzą oni wewnątrz ówcześnie istniejącej zbiorowości społeczność mniejszą, jakościowo inną, jakby „republikę przyjaciół” połączonych wspólnym światopoglądem, moralnością; żyjąc „według cnoty”, będąc posłuszni przekonaniu wewnętrznemu, w pełni realizują swoje człowieczeństwo, w przeciwieństwie do całej ogromnej reszty, która, jak ironicznie zauważa pasterz, wywiesza przed domami szyldy z napisem „Tu się szczycą nazwiskiem obywatela!”, szczepi drzewa wolności na rynkach miast, nie zaś w sercach, a religię traktuje zewnętrznie i instrumentalnie. Owa „republika przyjaciół” jest zbiorowością rozproszoną i mikroskopijną $w$ porównaniu $z$ resztą ludzkości, stąd też realizowane przez nią człowieczeństwo jest prawie niezauważalne w skali ogółu, jednakże to właśnie ona jako ów związek pojedynczych przyjaciół cnoty i człowieka, żyjących w konkretnej rzeczywistości, stanowi zalążek przyszłej, nowej ludzkości - społeczności ludzi cnotliwych, a równocześnie orientuje historię ku idei „wieku złotego”, zamieniając ideę ową z utopii lokowanej w mitycznej przeszłości na umiejscowiony w przyszłości moralny punkt dojścia historii (czyli punkt możliwie pełnej realizacji wartości moralnych przez całą ludzkość, której historia — w znaczeniu rozwoju wiedzy, kultury czy techniki — dalej będzie się toczyć), realnie osiągalny i przez niektóre jednostki — w tym przypadku przez alpejskiego pasterza — już osiągnięty.

Modyfikacja zawartego w liście generała Kosińskiego motywu szczęśliwego górala dokonana przez Godebskiego polegałaby zatem na zdecydowanym usunięciu tendencji eskapistycznej z pola sugerowanych przez ten motyw znaczeń i na przypisaniu mu funkcji stałego punktu odniesienia dla poszczególnych zmian historycznych, punktu zapewniającego każdemu cnotliwemu uczestnikowi owych zmian właściwe rozeznanie w ich przebiegu. Taką funkcjonalizację motywu umożliwia symbolika miejsca, w którym rozciąga się pasterska ustroń.

Lokalizacja siedziby pasterza na górze, trudność wspięcia się na szczyt, a następnie zejścia, wreszcie dosłowne przyznanie owej siedzibie miana „górskiego przybytku”, w którym spełnia się idea „wieku złotego”, nakazują w myśl powszechnie przyjętej symboliki góry potraktować kontakt z rzeczywistością sabaudzkiego otium jako rodzaj epifanii — odsłonięcia istotnych praw dotyczących powołania człowieka w historii, człowieka jako jednostki społecznej. Narrator - przypadkowy gość w tej alpejskiej ustroni, doskonale odczuwa epifaniczność swojego aktualnego doświadczenia, sporządzając $w$ formie elegii jakby zwięzły sumariusz poznanych tu bezpośrednio, naocz-

t. 10, 1964, s. 36: „...prawo utożsamia siç tu z wewnętrznym, rozumnym nakazem moralnym, realizuje siç spontanicznic, nic wymaga żadnych sankcji. Znika tu wszclki rozdźwiçk między uniwersalizmem prawa a partykularyzmem indywiduów. Wspólnota polityczna zasadzająca sic̨ w prawie utożsamia się tu z cmocjonalną wspólnotą moralno-obyczajową, w której identyfikacja jednostki ze społecznością jest całkowita i niemal bezrefleksyjna". 
nie stwierdzalnych w przejawach swojego funkcjonowania, wzorowych, wywiedzionych z uczucia moralnego prawideł życia człowieka społecznego.

Zamykający elegię czterowiersz:

Taki byłeś za naszych ojców, czasie złoty!

Potomki snem być mienią ich szczęście i cnoty;

A z czasu, w jakim sami żyją, biorąc miarę,

Słodzą go, między bajki kładąc wieki stare ${ }^{19}$

- jak również symboliczne zejście z alpejskiego szczytu, na którym mieści się szczęśliwa ustron („Oddalając się od tego szczęsnego pobytu rozumieliśmy, że rzucamy wiek złoty i wracamy do żelaznego” ${ }^{20}$ interpretowano zazwyczaj dosłownie, zestawiając z początkiem Wiersza do Legiów polskich:

...jeden $z$ narodów $w$ tej płonnej nadziei,

Że wieku żelaznemu wiek zwróci Astrei,

Chciał świata moralnego dawną burzyć postać...

— co, rzecz jasna, prowadzi do przypisania refleksjom Godebskiego nad ideą „złotego wieku” pesymistycznej wykładni. Tak czyni Zbigniew Kubikowski, przytoczywszy fragment listu Kosińskiego do Godebskiego, zawierający motyw wolnego „mieszkańca gór”, przechodzi do interpretacji wątku związanego z gospodarzem alpejskiej ustroni, ujawniając przy tym wyraźną niechęć do tej fikcyjnej w końcu postaci:

Zajmijmy się postulatami listu, mitem pasterza. Nie chodziło tu bynajmniej o rzeczywistego pasterza alpejskiego — nasuwał on jedynie legionistom ulubione reminiscencje z literatury klasycznej, pozwalał Trojańczykom porównywać swój los z ,wiekiem złotym”. Brudnego [sic! — A. T.] pasterza sabaudzkiego ubrano w barwy i szaty Owidiusza, widząc w micie wolnego górala możliwość takiej ucieczki, jaką Kniaziewicz znalazł w kraju na solidnej dzierżawie. (...) ...,wiek złoty" na alpejskich szczytach - wymarzona ucieczka Kosińskiego - pozwalał westchnąć do czasów, kiedy „Podłość nie ubóstwiała niszczycielów świata; / Człek w rządcy widział ojca, rządca w człeku brata". Ta wycieczka w antyczną legendę nie mieściła się jednak w realistycznej fakturze powieści. (...) ...żyjący w odosobnieniu pastuch [sic! - A. T.] ma świeży, bezpośredni sąd o wszystkim, co się dzieje w dolinach ${ }^{21}$.

Tymczasem ani wstęp poematu o Legionach, ani owe cztery wersy wykładu prawideł organizujących podstawy porządku społecznego nie dają właściwie powodu do takiej interpretacji. W obu przypadkach idea "wieku złotego" jako postulat stawiany historii nie jest przecież wcale zakwestionowana; w Wierszu do Legiów polskich mowa tylko o niewłaściwej metodzie jej realizo-

${ }^{19}$ C. Godebski, op. cit., s. 26.

20 Ibidem, s. 29.

${ }^{21}$ Z. Kubikowski, Wstęp, w: C. Godcbski, op. cit., s. XXXIII-XXXV. 
wania, zaś w rozdziale IV Grenadiera-filozofa przybliżanie się do niej jest przecież realizowane hic et munc w codzienności pasterskiej ustroni, czyli w jakiejś mikroskali, jeśli idzie o ogólnie pojętą historię, co daje asumpt do przypuszczeń, że i w skali makro ma szansę na urzeczywistnienie, tym bardziej jeśli uwzględni się podzielany przez narratora - porte parole Godebskiego - russowski kontekst myśli o „wieku Astrei”22. Nadto, czterowiersz zamykający elegię o „czasie złotym”, rozpatrywany $\mathrm{w}$ zestawieniu z przeżywanym przez narratora doświadczeniem przybliżania się ku pełni realizacji idei „wieku złotego”, doświadczeniem będącym także udziałem współtowarzysza wędrówki - kapitana Michalewskiego, a więc doświadczeniem jakby zobiektywizowanym, posiada zupełnie inną wymowę niż przypisywany mu pesymizm historiozoficzny. Fragment ów mówi mianowicie o błędnym, a zatem rodzącym nieład w sferze historii, ustosunkowaniu się ludzi do tejże idei, wynikającym z fałszywej przesłanki, to jest brania miary (czyli wzorcowego wyobrażenia o układzie, porządku, strukturze rzeczywistości) „z czasu, w jakim sami żyją”, czyli z historii, a dokładniej rzecz ujmując - z ostatniego, współczesnego sobie etapu historii, z teraźniejszości, która dopiero staje się historią. Natychmiastowym skutkiem takiego brania miary jest ulokowanie idei „wieku złotego” w dziedzinie płonnych marzeń, gdy tymczasem - co jednoznacznie wynika z praktyki życiowej pasterza alpejskiego i pozostałych, cnotliwych i zarazem czułych bohaterów powieści — idea ta wina być umiejscowiona w rzeczywistości dziejowej (jako swoisty terminus ad quem), podstawą zaś takiego umiejscowienia stanowi wzięcie miary nie z porządku historii, lecz z porządku natury.

Idea „złotego wieku”, tkwiąca immanentnie w procesie dziejowym i w swojej istocie będąca jakby jednym z wariantów Kantowskiego połączenia moralności i polityki ${ }^{23}$, wyznaczała kierunek postępu historii i... nadawała sens wojnie. To usensownienie najwyraźniej dostrzec można w Wierszu do Legiów polskich, w którym podmiot liryczny zdecydowanie oddziela utopijną dążność do natychmiastowej niemal i dosłownie pojętej restytucji „wieku złotego” w warunkach „wieku żelaznego" od jak najbardziej koniecznych, moralnie uzasadnionych działań, podejmowanych w zgodzie z intencją przekształcania, bolesnego i długotrwałego, rzeczywistości historycznej, regulowanego właśnie ideą „wieku Astrei”:

Kiedy jeden $z$ narodów w tej płonnej nadziei,

Że wieku żelaznemu wiek zwróci Astrei,

22 Zob. J. Szacki, Rousseau: utrata i odzyskanie wolności, w: Antynomie wolności. Z dziejów filozofii wolności, Warszawa 1966, s. 243. O antyeskapistycznej wykładni idei „stanu naturalnego” w filozofii J.J. Rousscau piszc: „(...) hipoteza "stanu naturalnego" rzadko miewała charakter hipotezy historyczncj. (...) Idealizując "stan naturalny» nic zaleca siç bowicm ludziom powrotu do owego domniemanego wicku złotego, nic namawia siç ich - jak imputował to autorowi Rozprawy [o pochodzeniu i podstawach nierówności między ludźmi — A. T.] Voltairc — by zaczçli chodzić znowu na czworakach. (...) Można tęsknić do pierwotncj idylli, ale nie sposób jej wznowić. (...) Człowick powinien być wolny, ale jcgo wolność w społcczeństwie nie możc już być tą samą wolnością, jaką cieszył się na łonic natury. Wicdza o tej ostatniej jest mu potrzcbna, aby w szansę wolności uwierzyl i bronil swego naturalnego prawa pamiçtając, że jest ono nicodłączne od jego człowicczeństwa. Ale tylko tyle. Odzyskanic utraconcj wolności może nastąpić tylko w drodze zdobycia wolności w społeczeństwie, którego człowiek nic może już opuścić" [podkr. - A. T.]. ${ }_{23}$ Zob. K. Bal, Kantowska fenomenologia świadomości moralnej, w: idem, Kant i Hegel. Dwa szkice z dziejów niemieckiej mysti etycznej, Wrocław 1994, s. 38-40. 
Chciał świata moralnego dawną burzyć postać,

Polak pragnął szczególnie swą własność wydostać (...)

Wy, czując w sercach waszych cnotorodny płomień,

Szliście tam, gdzie nadziei prowadził was płomień,

Płomień, na który blednie występek i zdrada!

On dla nich strasznym błyskiem, w którym grom wypada... 24

Wojnom prowadzonym przez republikańską Francję i walczących u jej boku Polaków-legionistów, owemu burzeniu „starego" świata, podmiot wiersza, a z nim także Godebski — uczestnik kampanii włoskiej i niemieckiej - nadawał sens moralny, spoglądając na nie „ze wzniesionej nauki wzgorza”, na którym przebywał wespół z mądrym pasterzem sabaudzkim. Styk „dwóch światów" mógł więc oznaczać nie tylko zetknięcie się historii i moralności, ale również zespolenie gwałtownej zmiany dziejowej -- wojny z ideą „wieku złotego”.

${ }^{24}$ C. Godebski, Wybór wierszy..., op. cit., s. 12, 13. 